\title{
PERSPECTIVAS PARA REDUÇÃO DAS DESIGUALDADES SOCIOAMBIENTAIS GERADAS PELA NÃO CONCRETIZAÇÃO DO DIREITO HUMANO DE ACESSO À ÁGUA
}

\author{
PERSPECTIVES FOR REDUCING SOCIAL AND ENVIRONMENTAL \\ INEQUALITIES GENERATED BY NOT ACHIEVING THE HUMAN RIGHT TO \\ WATER ACCESS
}

\section{PERSPECTIVAS PARA REDUCIR LAS DESIGUALDADES SOCIALES Y AMBIENTALES GENERADAS POR NO LOGRAR EL DERECHO HUMANO AL ACCESO AL AGUA}

\author{
JEFERSON DYTZ MARIN \\ https://orcid.org/0000-0002-7241-5243 / http://lattes.cnpq.br/0169455265201716 / jeferson@marinadv.com.br \\ Universidade de Caxias do Sul - UCS \\ Caxias do Sul, RS, Brasil \\ CAROLINE FerRi BURGEL \\ https://orcid.org/0000-0002-3970-6751 / http://lattes.cnpq.br/0566112514633009 / cfburgel@gmail.com
}

Universidade de Caxias do Sul - UCS Caxias do Sul, RS, Brasil

\begin{abstract}
RESUMO
As iniquidades socioambientais, especificamente o acesso precário à água e ao saneamento básico, geram desigualdades sociais e econômicas preocupantes. Pode-se legislar sobre o direito de acesso à água e ao saneamento básico, projetar políticas públicas, porém é preciso que esses projetos sejam eficazes e promovam o acesso equânime aos recursos básicos à dignidade humana. O objetivo desta pesquisa é analisar a falta de acesso à água e ao saneamento como fator gerador de desigualdades socioambientais e demonstrar perspectivas para a redução dessas desigualdades. As metodologias principais são a qualitativa e analítica. Para a compreensão do tema aborda-se bibliografias específicas sobre o contexto socioambiental, utilizando como exemplo países da América Latina, e documentos que demonstram as estimativas da população que não possui acesso e, como consequência, se encontra em situação de pobreza. Depreende-se desse estudo a necessidade de renovar o olhar sobre a utilização dos recursos hídricos, entendendo que é um bem comum e que o seu uso deve ser pautado nos valores constantes do princípio da solidariedade.
\end{abstract}

Palavras-chave: Água e Saneamento Básico. América Latina. Bens Comuns. Desigualdade Social. Direitos Humanos.

ABSTRACT

Socio-environmental inequalities, specifically poor access to water and sanitation, generate worrying social and economic inequalities. It's possible to legislate about the right to water and sanitation access, or create public policies, but these projects need to be effective and promote equitable access to basic resources for human dignity. The objective of this research is to analyze the lack of access to water and sanitation as a factor that generates social and environmental inequalities and to demonstrate perspectives for the reduction of these inequalities. The main methodologies are qualitative and analytical. To understand the theme, specific bibliographies about the social and environmental context are approached, using Latin American countries as example, and documents that demonstrate the estimative of the population that does not have access and is in poverty consequently. It emerges from this study the need to renew the view on the use of water resources, understanding that it is a common good, and its use should be based on the values contained in the principle of solidarity.

Keywords: Water and Sanitation. Latin America. Common Goods. Social Inequality. Human Rights. 


\section{RESUMEN}

Las desigualdades socioambientales, específicamente el acceso deficiente al agua y al saneamiento, generan inquietantes desigualdades sociales y económicas. Puede legislar sobre el derecho de acceso al agua y al saneamiento, diseñar políticas públicas, pero estos proyectos deben ser efectivos y promover el acceso equitativo a los recursos básicos para la dignidad humana. El objetivo de esta investigación es analizar la falta de acceso al agua y al saneamiento como un factor que genera desigualdades sociales y ambientales y demostrar perspectivas para la reducción de estas desigualdades. Las principales metodologías son cualitativas y analíticas. Para comprender el tema, se abordan bibliografías específicas sobre el contexto social y ambiental, utilizando como ejemplos países latinoamericanos, y documentos que demuestran las estimaciones de la población que no tiene acceso y está en pobreza como consecuencia. De este estudio surge la necesidad de renovar la visión sobre el uso de los recursos hídricos, entendiendo que es un bien común, y su uso debe basarse en los valores contenidos en el principio de la solidaridad.

Palabras clave: Agua y saneamiento básico. América Latina. Bienes comunes. Desigualdad social. Derechos humanos.

\section{SUMÁRIO}

INTRODUÇÃO; 1 ASPECTOS SOCIAIS E AMBIENTAIS SOBRE A FALTA DE ACESSO À ÁGUA E AO SANEAMENTO BÁSICO; 2 FALTA DE ACESSO À ÁGUA E AO SANEAMENTO BÁSICO COMO FATOR GERADOR DE DESIGUALDADES SOCIOAMBIENTAIS; 3 REFLEXÕES SOBRE PERSPECTIVAS PARA A REDUÇÃO DAS DESIGUALDADES SOCIOAMBIENTAIS GERADAS PELA FALTA DE ACESSO À ÁGUA E AO SANEAMENTO; CONCLUSÃO; REFERÊNCIAS.

\section{INTRODUÇÃO}

O propósito deste artigo é analisar como o acesso à água potável e ao saneamento básico impacta na construção/promoção do acesso à justiça socioambiental a partir da relação entre desigualdade socioeconômica e distribuição de recursos naturais, em um contexto neoliberal. Esse problema perpassa a esfera da justiça socioambiental, das desigualdades sociais, dos direitos humanos e do direito de acesso à água e ao saneamento básico. Com isso, pretende-se analisar perspectivas sobre a distribuição da água para diminuição das desigualdades socioambientais, tecendo alguns exemplos presentes na América Latina.

A distribuição equivocada da água pode ser uma fonte de conflitos ecológicos que resultam em injustiças socioambientais. Os povos, as comunidades, cada grupo social abarca uma cultura e formas variadas de relação com a natureza, provocando impactos positivos e negativos em diversas proporções. Aborda-se o conceito de justiça ambiental no contexto deste estudo a partir do reconhecimento de que as consequências da falta de acesso à água e ao saneamento básico significa a negação de direitos humanos, especialmente o direito à uma vida digna, com o mínimo de qualidade e existencial para a sua manutenção.

No Brasil, a Política Nacional dos Recursos Hídricos, Lei n 9.433 de 1997, determina que a utilização dos recursos hídricos deve servir prioritariamente ao abastecimento humano. Dessa 
ISSN 1981-3694

(DOI): $10.5902 / 1981369432544$

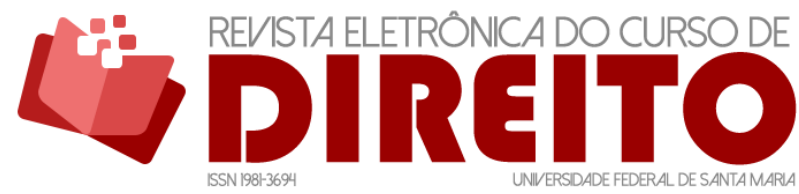

PERSPECTIVAS PARA REDUÇÃO DAS DESIGUALDADES SOCIOAMBIENTAIS GERADAS PELA NÃO CONCRETIZACÃO DO DIREITO HUMANO DE ACESSO Å ÁGUA

forma, verifica-se que a água não pode ser, deliberadamente, utilizada para interesses lucrativos. Sob esse ponto de vista, a melhor maneira de gerenciar esse recurso seria por meio de uma política distributiva equânime, diferente da visão economicista, que compreende a água como um recurso escasso, utilizado sob a lógica da oferta e da demanda. O levantamento de alternativas não implica em trazer soluções únicas, mas sim possibilidades de readequar a distribuição das águas, nos seus diferentes usos, para redução das desigualdades socioambientais, assim como a construção de uma percepção holística, compreendendo o recurso como um bem comum, isto é, para todos.

Como pontos principais, aborda-se a dimensão ecológica da dignidade humana com ênfase na importância da água para sua manutenção. Da mesma forma, levanta-se a saúde humana como um fator chave para a construção das liberdades individuais, cuja relação com a água é estrita, uma vez que, havendo escassez (ou má distribuição) desta, a vida digna em um ambiente ecologicamente equilibrado resta prejudicada.

Para o enlace do objetivo proposto, que se traduz na identificação da falta de água e de saneamento básico como fator gerador de desigualdades socioambientais e na busca de perspectivas para a construção e concretização de outro olhar sobre o problema, trabalha-se os aspectos socioambientais da água, verificando estimativas sobre o impacto da falta de acesso aos recursos hídricos. No segundo tópico, é verificada a relação da falta de acesso à água e ao saneamento básico com as desigualdades socioambientais. Ao fim, reflete-se sobre diferentes perspectivas para se pensar e atuar pela redução das desigualdades decorrentes da problemática em tela. Achega-se à ideia de que a transformação cultural, não só dos governantes, mas da própria sociedade, é necessária e útil ao processo de mudança da sociedade na busca por justiça àqueles que estão às suas margens.

A Constituição da República Federativa do Brasil de 1988 é clara ao dispor, no artigo 225, sobre o direito ao meio ambiente ecologicamente equilibrado, cuja qualidade importa por ser essencial à sadia qualidade de vida. Estatísticas demonstram que há água de qualidade, contudo, há má distribuição. Deduz-se que a transformação dessa realidade de desigualdade na distribuição de bens comuns depende da organização de grupos sociais cujo interesse talvez nem seja o mesmo, isto é, diferentes classes sociais que se mobilizem para a construção de uma nova cultura. Um modo de perceber a desigualdade são os frutos produzidos pela conjuntura política, econômica, social e cultural de determinado País, que podem se apresentar por meio de indicadores como o índice de Gini, que mensura a concentração de renda e de desigualdade social de um País de forma diversa dos índices comumente utilizados, como o PIB e a taxa de 
ISSN 1981-3694

(DOI): $10.5902 / 1981369432544$

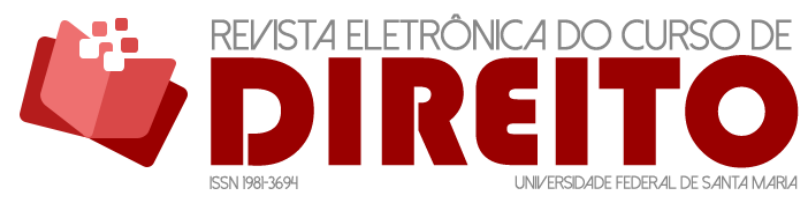

PERSPECTIVAS PARA REDUÇÃO DAS DESIGUALDADES SOCIOAMBIENTAIS GERADAS PELA NÃO CONCRETIZACÃ̃O DO DIREITO HUMANO DE ACESSO Å ÁGUA

inflação. A pesquisa em tela se assenta sob esse espectro, buscando elementos que possam aclarar a desigualdade gerada pela falta de acesso à água e ao saneamento básico.

A abordagem metodológica utilizada é a qualitativa, onde se busca a compreensão dos conceitos utilizados relacionados aos dados coletados em documentos oficiais da Organização das Nações Unidas, para refletir sobre a dinâmica distributiva dos recursos hídricos vigente. Quanto à natureza a pesquisa é básica e, embora não se proponha a criação de uma nova perspectiva, busca-se verificar, a partir das informações levantadas, formas que possam ser adequadas à resolução da problemática ou de minimização dos seus danos aos aspectos sociais e ambientais. A pesquisa é exploratória em relação ao seu objetivo, onde se intenciona estudar o tema para criar familiaridade com o problema e tornar explícitas as hipóteses e premissas observadas ao final; essa etapa consiste no levantamento e na definição da bibliografia utilizada e na análise de exemplos que estimulam a compreensão e ilustram a temática. Também é realizada a pesquisa descritiva, uma vez que são analisados documentos como os relatórios da ONU sobre o assunto.

\section{ASPECTOS SOCIAIS E AMBIENTAIS SOBRE A FALTA DE ACESSO À ÁGUA E AO SANEAMENTO BÁSICO}

A falta de acesso à água e saneamento básico pode implicar diretamente na geração de desigualdades sociais. Com o propósito de analisar essa afirmativa faz-se um levantamento de dados que estimam a realidade em relação à distribuição dos recursos hídricos, como também sobre seus aspectos ambientais e sociais. Destaca-se a importância da água, pois é um direito humano com relação estrita à dignidade da pessoa humana. Este estudo remete à dimensão ecológica da dignidade, percebendo a manutenção da qualidade de vida humana conectada e dependente de um meio ambiente ecologicamente equilibrado. Nesse sentido, se apresenta o dispositivo constitucional (artigo 225, da Constituição Federal de 1988), considerado pela autora Norma Sueli Padilha ${ }^{1}$ uma inovação em relação às outras constituições.

$O$ direito ao meio ambiente ecologicamente equilibrado passou a ser reconhecido como de terceira dimensão, ou seja, um direito difuso e coletivo, cuja implementação é solidária e de titularidade humanitária. A proposta constitucional vigente é a convivência da preservação

1 PADILHA, Norma Sueli. Fundamentos Constitucionais do Direito Ambiental Brasileiro. Rio de Janeiro: Elsevier, 2010. p. 157. 
ambiental com todos os setores sociais, políticos e, especialmente, econômicos. Com essa percepção gera-se, na legislação brasileira, um novo viés jurídico pautado na ideia de desenvolvimento sustentável aos moldes da Conferência das Nações Unidas sobre o Meio Ambiente de 1972. A Declaração de Princípios resultante desse evento afirma o homem como um ser que interage com a natureza, da qual retira o seu sustento, e, por isso, é lógico que a preservação e o melhoramento do meio ambiente são inerentes à manutenção do bem-estar populacional e do desenvolvimento econômico em um nível global. Desse modo, se tornou, especialmente por meio de uma consciência coletiva, um direito humano e fundamental, promovendo a criação de legislações ambientais e regulações em diversos países. ${ }^{2}$

Em que pese muito se alerte sobre a importância da utilização consciente da água e da sua distribuição justa em pautas de convenções, tratados e como tema principal de Fóruns, somente em 2010 a Assembleia Geral da Organização das Nações Unidas, na Resolução 64/292 $(\mathrm{AG})^{3}$, reconheceu a água como um direito humano no plano internacional. Brzezinski aponta que a doutrina, em parte, entende que o direito humano à água está integrado a direitos como vida, saúde, alimentação e moradia. ${ }^{4}$ Além disso, seria possível abstrair a água com tal status do artigo 25, $1^{5}$, da Declaração Universal dos Direitos Humanos, dentre outros documentos que se reportam aos direitos mencionados ou semelhantes, no sentido de que não se concretizam sem o acesso à água.

A dignidade humana em uma dimensão ecológica ou socioambiental é constituída também pelo direito referido. A água, como mantenedora da vida, constitui o ambiente em que os seres convivem e se desenvolvem. O objetivo dessas premissas é promover padrões de qualidade e de segurança ambiental adequados. A qualidade ambiental é elementar para

\footnotetext{
2 PADILHA, Norma Sueli. Fundamentos Constitucionais do Direito Ambiental Brasileiro. Rio de Janeiro: Elsevier, 2010. p. 45, 157.

3 ASSEMBLEIA GERAL DA ONU (AG). Resolução 64/292. AG Index: A/RES/64/292, 28 de julho de 2010. Disponível em: http://www.un.org/en/ga/search/view_doc.asp?symbol=A/RES/64/292. Acesso em 06 ago. 2017.

${ }^{4}$ BRZEZINSKI, Maria Lúcia N. L. O Direito à Água no Direito Internacional e no Direito Brasileiro. Niterói: Confluências, v. 14, n. 1, dez. 2012. Disponível em: http://www.confluencias.uff.br/index.php/confluencias/article/viewFile/296/240. Acesso em 09 ago. 2017.

${ }^{5}$ Toda a pessoa tem direito a um nível de vida suficiente para the assegurar e à sua família a saúde e o bem-estar, principalmente quanto à alimentação, ao vestuário, ao alojamento, à assistência médica e ainda quanto aos serviços sociais necessários, e tem direito à segurança no desemprego, na doença, na invalidez, na viuvez, na velhice ou noutros casos de perda de meios de subsistência por circunstâncias independentes da sua vontade.
} 
proporcionar as bases naturais e existenciais necessárias ao desenvolvimento da vida humana em toda a sua potencialidade. ${ }^{6}$

A falta de acesso à água e ao saneamento básico é um fator prejudicial à saúde ambiental e social e é geradora de conflitos sociais e ambientais. A justiça ambiental, enquanto um conceito que envolve a manutenção da qualidade de vida pautada no acesso e na distribuição dos recursos ambientais de forma equânime, permeia esse contexto, não sendo promovida na medida em que não o é o direito humano de acesso à água em seus múltiplos usos. De acordo com Gregorio Mesa Cuadros, as injustiças provenientes da distribuição dos recursos ambientais é um dos pontos formadores dos conflitos ambientais, mas não somente isso. A degradação do meio ambiente também as provoca, negando, sob o olhar da solidariedade, às presentes e às futuras gerações o acesso equânime aos recursos naturais. O conflito ambiental é uma noção essencialmente relacionada com as disputas por parte de diversas comunidades, povos e Estados sobre o acesso, a extração, o uso, a transformação, a produção, o controle e a degradação ambiental. Os movimentos sociais dão início ao reclame por justiça frente a esses conflitos. ${ }^{7}$

Gregorio Mesa Cuadros aponta que justiça inter-intrageracional, energética, hídrica, dentre outros, são elementos do conceito de justiça ambiental, que engloba também práticas de povos e culturas que buscam a construção de horizontes jurídicos, políticos e éticos pautados em propostas de desenvolvimento a favor da vida e da dignidade humana e de todos os seres vivos. A construção dessa percepção, para o autor, precisa ser pensada a partir da integralidade dentro da esfera ambiental. Significa que o ser humano é considerado parte do ambiente tanto quanto a natureza, e, portanto, é pauta da discussão a distribuição e redistribuição dos recursos naturais, com a participação dos governos para que se promova a sustentabilidade. ${ }^{8}$

Henri Acselrad ${ }^{9}$ entende que a construção da ideia de justiça ambiental passa por dois pontos: a distribuição objetiva dos efeitos ambientais das práticas sociais e a instituição dos esquemas de representação do mundo, do ambiente e de justiça, que podem vir a colocar em risco a legitimidade do primeiro ponto. O autor relaciona a crise ecológica à concepção

${ }^{6}$ FENSTERSEIFER, Tiago. Direitos fundamentais e proteção do ambiente: a dimensão ecológica da dignidade humana no marco jurídico constitucional do estado socioambiental de direito. Porto Alegre: Livraria do Advogado, 2008.

7 CUADROS, Gregorio Mesa. Uma Ideia de Justicia Ambiental: Elementos de conceptualización y fundamentación. Bogotá: Universidade Nacional de Colombia, 2018.

8 Ibidem.

9 ACSELRAD, Henri. Justiça ambiental e construção social do risco. Desenvolvimento e Meio ambiente, [s.l.], v. 5, p.49-59, 19 jun. 2002. Universidade Federal do Paraná. http://dx.doi.org/10.5380/dma.v5i0.22116. Disponível em: https://revistas.ufpr.br/made/article/view/22116/14480. Acesso em: 02 dez. 2019. 
ISSN 1981-3694

(DOI): $10.5902 / 1981369432544$

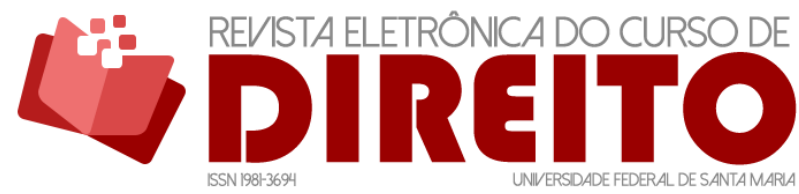

PERSPECTIVAS PARA REDUÇÃO DAS DESIGUALDADES SOCIOAMBIENTAIS GERADAS PELA NÃO CONCRETIZACÃO DO DIREITO HUMANO DE ACESSO Å ÁGUA

mercadológica e ao sistema capitalista, que opera de acordo com a demanda e a oferta, quando na realidade outros elementos relacionados à distribuição de bens ambientais deveriam ser enfatizados. A ideia de que a injustiça ambiental está relacionada à degradação ambiental não comporta depositar a confiança no mercado como sujeito ativo para superação da desigualdade ambiental e, consequentemente, da concretização da justiça ambiental.

$\mathrm{O}$ acesso à justiça ambiental pode ser concretizado por meio do Poder Judiciário tanto quanto por meio de políticas públicas setoriais que promovam o exercício efetivo de direitos, especialmente daqueles que estão em situação de vulnerabilidade. Flávia Piovesan adere ao conceito mais amplo da justiça para justiça social, em que se busca igualdade de oportunidades e permite à pessoa viver dentro de um contexto social com a garantia mínima de ter o necessário à sua dignidade ${ }^{10}$. A justiça, sob esse ponto de vista, pode ser compreendida como um serviço público que deve ser prestado com qualidade. Deduz-se que a disponibilidade do serviço de saneamento e de água para consumo deve se dar na mesma lógica. A injustiça se estabelece, nesse caso, no momento em que existem pessoas, sejam estas consideradas em quantidades significantes ou não, expostas aos efeitos da escassez em quaisquer das suas formas, pela degradação ambiental ou pela má distribuição dos recursos hídricos.

Para Bernardo Kliksberg, a água potável constitui um aspecto crítico em relação às iniquidades em termos de saúde. A OPAS (Organização Pan Americana da Saúde) aponta dados de 2008, referentes ao ano de 2006, sobre o acesso permanente à água, que demonstraram desigualdades significantes entre os ambientes urbanos e rurais da América Latina. Observa-se que em média $10 \%$ da população não tinha acesso à água potável no Panamá, Venezuela, Peru, Paraguai, El Salvador, Nicarágua, Bolívia, Honduras e Guatemala, e aproximadamente há 50 milhões de pessoas sem acesso à água potável. Há também uma segmentação socioeconômica, que se observa por dados como os do Peru, que demonstram que, em 2006, “ $100 \%$ dos $20 \%$ mais ricos dispunham de água potável”, essa taxa em relação aos 20\% mais pobres cai para 25\%; a mesma estimativa na Colômbia se apresentava, contudo, dos $20 \%$ mais pobres, apenas $41 \%$ possuíam acesso à água encanada ${ }^{11}$.

Além dos pobres possuírem dificuldade de acesso, acabam por despender mais ao comprá-la do que os ricos, isto é, os gastos com água ocupam um espaço no orçamento familiar

\footnotetext{
${ }^{10}$ PIOVESAN, Flávia. Temas de direitos humanos. 2.ed. rev. ampl. e atual. São Paulo: M. Limonad, 2003.

11 SEN, Amartya; KLIKSBERG, Bernardo. As pessoas em primeiro lugar: a ética do desenvolvimento e os problemas do mundo globalizado. São Paulo: Companhia das Letras, 2010. Tradução de: Bernardo Ajzemberg e Carlos Eduardo Lins da Silva. p. 175.
} 
maior do que no orçamento de uma família rica. ${ }^{12}$ Em que pese esses dados sejam desse período, hoje ainda há números que indicam desigualdades sociais e ambientais preocupantes. A OPAS, em 2019, emitiu uma reportagem alertando para o fato de que, segundo dados de 2017, 15,5 milhões de pessoas ainda defecam a céu aberto na América Latina e no Caribe. ${ }^{13}$

Concretamente, pode-se perceber a indisponibilidade da água através das estimativas realizadas pelo WHO/UNICEF - que, em monitoramento conjunto do Programa de Abastecimento de Água, Saneamento e Higiene, tem levantado dados desde 1990 em países de diferentes níveis de desenvolvimento. A atualização de 2017 traz informações preocupantes, pois demonstram um grande número de pessoas sem acesso à água. De acordo com o Progress on Drinking Water, Sanitation and Hygiene: 2017 Update and Sustainable Development Goal Baselines (Progressos em matéria de água potável, saneamento e higiene: atualização de 2017 e relativas aos Objetivos de Desenvolvimento Sustentável [ODS]), 844 milhões de pessoas, em 2015, não possuem acesso à água potável para consumo; 263 milhões de pessoas precisam caminhar, ida e volta, mais de 30 minutos para coletar água de uma fonte de melhor aspecto e, consta que 2,1 bilhões de pessoas têm acesso à água potável de uma fonte insegura; sobre o saneamento, 2,3 bilhões de pessoas não possuem serviço sanitário, 892 milhões de pessoas no mundo praticam defecação aberta. ${ }^{14}$

Segundo Bernardo Kliksberg, o problema da água, principalmente na região da América Latina, não tem relação com a disponibilidade da água, mas sim com a sua distribuição. Exemplificam através de Lima (Peru), em que $60 \%$ da população recebem $12 \%$ do total da água distribuída pela cidade. Além disso, o Peru está entre os países do mundo que mais contém água doce do Planeta, e ainda assim é um país onde as pessoas pobres tem o acesso precário. ${ }^{15}$ Por ter uma grande região desértica, o abastecimento nesses locais precisa ser realizado por caminhões pipa, através de poços artesianos, rios, valas ou nascentes, e relata-se que a qualidade da água na maioria das vezes não é adequada e o abastecimento pode não ser seguro.

\footnotetext{
12 SEN, Amartya; KLIKSBERG, Bernardo. As pessoas em primeiro lugar: a ética do desenvolvimento e os problemas do mundo globalizado. São Paulo: Companhia das Letras, 2010. Tradução de: Bernardo Ajzemberg e Carlos Eduardo Lins da Silva. p. 176.

13 ORGANIZAÇÃO PAN-AMERICANA DA SAÚDE (Brasil). Quase 16 milhões de pessoas ainda defecam ao ar livre na América Latina e no Caribe. 2019. Disponível em: https: / / www.paho.org/bra/index.php?option=com_content\&view=article\&tid=6063:quase-16-milhoes-depessoas-ainda-defecam-ao-ar-livre-na-america-latina-e-no-caribeqltemid=839. Acesso em: 02 dez. 2019.

${ }_{14}^{14}$ WHO/UNICEF. progress on Drinking Water, Sanitation and Hygiene: 2017 Update and SDG Baselines. Geneva: World Health Organization (WHO) and the United Nations Children's Fund (UNICEF), 2017. Disponível em: http://www.unicef.pt/artigo.php?mid=1810\&m=\&sid=181016\&cid=6345. Acesso em: $04 \mathrm{de}$ ago. 2017.

${ }^{15}$ SEN; KLIKSBERG, Op. Cit.
} 
Por vezes, ainda é caro para se obter esse recurso nessas regiões em razão do metro cúbico de água ter um valor maior para caminhões pipa.

Maria Lucia Brzezinski ${ }^{16}$ e Barlow e Clarke ${ }^{17}$ assinalam que $20 \%$ da população mundial consome $40 \%$ da água do planeta, e esse dado permite visualizar a desigualdade em relação à água, o que significa dizer que boa parte possui parco acesso, ou nenhum. Para Barlow e Clarke ${ }^{18}$ os hábitos e o estilo de vida fazem parte da causa, gerando consumo em excesso. Além dos hábitos cotidianos básicos, a construção e manutenção de piscinas, a irrigação de campos de golfe e o uso industrial da água, típicos de países desenvolvidos, são exemplos de consumo.

A autora Maria Lúcia Brzezinski esclarece que

a quantidade de água no planeta não aumentou, nem diminuiu, ela continua a mesma desde a pré-história. Contudo, o ciclo hidrológico - a forma como a água se movimenta pelas fases sólidas, líquida e gasosa - tem sido alterado pela ação humana, as águas são poluídas, contaminadas e mal utilizadas, a demanda continua a aumentar e a população continua a se concentrar nos lugares errados - embora haja quem diga que a água que está nos lugares errados e em quantidade errada. ${ }^{19}$

Países em desenvolvimento demandam um número maior de captação da água doce, pois ao passo que estão em crescimento, também está o padrão de vida e, portanto, a demanda por água, alimentos, em especial a carne, a energia, etc. 0 processo de urbanização acelerado é considerado outro fator de contribuição para o cenário de escassez de água. Nesse contexto, não só a escassez, mas também a qualidade da água importa. “A água de baixa qualidade pode não ser adequada para vários usos, e o custo necessário para seu tratamento pode ser um fator proibitivo, contribuindo assim para o aumento do peso econômico da escassez de água."20.

A falta de saneamento básico, por sua vez, afeta seriamente a concretização de direitos humanos. No Brasil, segundo o Relatório de Desenvolvimento Humano (PNUD), em 2001 dois terços dos $20 \%$ mais pobres da população não possuíam banheiro. Em 2000 , de acordo com os dados da Pesquisa Nacional de Saneamento Básico, realizada pelo Instituto Brasileiro de

${ }^{16}$ BRZEZINSKI, Maria Lúcia N. L. Água doce no século XXI: serviço público ou mercadoria internacional? São Paulo: Lawbook Editora, 2009, p. 47.

17 BARLOW, Maude; CLARKE, Tony. Ouro azul: como as grandes corporações estão se apoderando da água doce do nosso planeta. São Paulo: M. Books, 2003.

18 Ibidem.

${ }^{19}$ BRZEZINSKI, op. cit., p. 28-29.

20 WWAP (United Nations World Water Assessment Programme). Relatório Mundial das Nações Unidas sobre Desenvolvimento dos Recursos Hídricos 2016: Água e emprego. Resumo executivo. Paris, UNESCO. 2016. Disponível em: http://unesdoc.unesco.org/images/0024/002440/244040por.pdf. Acesso em 04 ago. 2017. 
ISSN 1981-3694

(DOI): $10.5902 / 1981369432544$

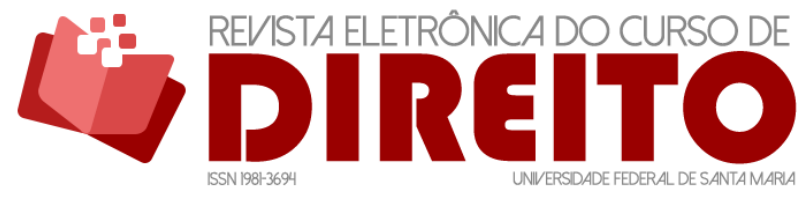

PERSPECTIVAS PARA REDUÇÃO DAS DESIGUALDADES SOCIOAMBIENTAIS GERADAS PELA NÃO CONCRETIZACÃO DO DIREITO HUMANO DE ACESSO Å ÁGUA

Geografia e Estatística, o serviço de abastecimento não era universalizado e, em 116 municípios brasileiros a população precisava buscar água em locais como chafarizes, fontes, poços particulares, dentre outras alternativas, por não haver abastecimento via rede geral, sendo a maior parte destes locais nas Regiões Norte e Nordeste.

Em 2010, uma nova pesquisa do IBGE relativa ao saneamento básico, referente ao ano de 2008, atualiza esses dados, sendo que o número de municípios sem rede geral de distribuição de água, em nenhum de seus distritos, diminuiu para 33 municípios, que são abastecidos por carros-pipas, poços particulares e chafarizes, bicas ou minas. A maior parte destes municípios, ainda, estão no Norte e no Nordeste. Na América Latina e no Caribe, houve uma melhora entre os anos de 2000 a 2017, e hoje, quase 75\% da população da América Latina e 33\% da população caribenha possuem acesso à água e ao saneamento de forma segura. Contudo, ainda há muito por fazer, por isso a OPAS entende que os países devem manter como prioridade a distribuição de água e de saneamento para aumentar o índice de acesso a esses recursos. ${ }^{21}$

O Sistema Nacional de Informações sobre Saneamento (SNIS) divulgou dados brasileiros referente ao ano de 2017. A região com maior índice de atendimento de abastecimento de água é a Sul, com 98,4\%, já o índice menor, de 70\%, é da região norte. De acordo com o SNIS, esse fato demanda que se aprimore a política de saneamento desenvolvida nos estados dessa região. De toda forma, é apontado um acréscimo de 912,8 mil ligações de água em relação a 2016 e 14,4 mil quilômetros de redes. Esses dados representam 1,1 milhão de pessoas que passaram a serem atendidas e abastecidas com água encanada. ${ }^{22}$ Apesar de os índices apontados demonstrarem que há uma movimentação positiva, ainda há ausência de saneamento básico no Brasil e no mundo. Tal fato pode estar relacionado com a crise ambiental global e complexa que se associa às “(...) desigualdades sociais, ao crescimento demográfico, ao desenvolvimento desorganizado das cidades que dificultam o acesso ao saneamento de forma igualitária". ${ }^{23}$

21 ORGANIZAÇÃO PAN-AMERICANA DA SAÚDE (Brasil). Quase 16 milhões de pessoas ainda defecam ao ar livre na América Latina e no Caribe. 2019. Disponível em: https://www.paho.org/bra/index.php?option=com_content\&view=article\&tid=6063:quase-16-milhoes-depessoas-ainda-defecam-ao-ar-livre-na-america-latina-e-no-caribeqltemid=839. Acesso em: 02 dez. 2019. 22 BRASIL. Sistema Nacional de Informações Sobre Saneamento. Ministério do Desenvolvimento Regional. Ministério do Desenvolvimento Regional publica diagnósticos da situação do saneamento no Brasil. 2019. Disponível em: http://www.snis.gov.br/component/content/article?id=175. Acesso em: $02 \mathrm{dez}$. 2019.

23 SANTOS, Ruth; MENEZES, Renata. A necessidade de realização de políticas públicas para a universalização do direito ao saneamento básico. Rev. Bras. Polít. Públicas (Online), Brasília, v. 6, $n^{\circ} 2$, 2016. p. 264-279. 
A gestão solidária, que prioriza a distribuição equânime e o uso sustentável, isto é, somente o necessário e na medida que não comprometa as presentes e futuras gerações, pode se tornar a lógica adequada para gerir recursos hídricos. Conforme o Relatório da ONU sobre Desenvolvimento dos Recursos Hídricos 2016: Água e Emprego, gerir sustentavelmente os recursos hídricos evita a poluição e a degradação. É preciso o investimento em infraestrutura básica, saneamento e acesso ao abastecimento seguro, bem como uma regulação justa, pois impacta diretamente no padrão de vida, expande a economia, gera empregos e promove a inclusão social. ${ }^{24}$ Pode-se dizer que a redistribuição dos recursos hídricos é imprescindível e a concretização dessas ações implica na efetivação de um desenvolvimento sustentável.

No contexto atual, milhares de pessoas morrem pela falta de acesso à água adequada para consumo humano, em suas diversas finalidades, e pela falta de saneamento básico, cuja ausência provoca inúmeras doenças como, por exemplo, a hepatite e a malária. Segundo a Organização Mundial da Saúde, a falta de saneamento básico mata 1,7 milhões de crianças, sendo que um quarto das mortes é de crianças menores de cinco anos e é causada por fatores ambientais, tais como a poluição e a falta de água própria para o consumo. ${ }^{25}$

A água é um recurso fundamental ao equilíbrio do ecossistema e à subsistência humana, bem como de todos os organismos vivos e, por óbvio, “(...) a disponibilidade, uso e gerenciamento dos recursos hídricos são fundamentais para o futuro sustentável da humanidade". ${ }^{26}$ No entanto, com o decorrer do tempo, esse recurso pode se tornar escasso não só no viés da economia, mas também na sua forma física. A sua depleção tem por consequência o aumento do custo, e em um contexto onde já é considerado injusto devido à distribuição desse bem, soma-se o fator econômico. 0 viés solidário e responsável para o planejamento e o gerenciamento dos recursos hídricos pode ser uma alternativa para contornar as desigualdades decorrentes dessa problemática. Enfatiza-se que a água é o elemento essencial à vida, e por si só essa afirmativa tem força para que a coletividade se insurja com o objetivo de defender o seu direito e a sua vida, tanto quanto a do outro. Ora, "o corpo de um ser adulto contém $75 \%$ do seu

${ }^{24}$ WWAP (United Nations World Water Assessment Programme). Relatório Mundial das Nações Unidas sobre Desenvolvimento dos Recursos Hídricos 2016: Água e emprego. Resumo executivo. Paris, UNESCO. 2016. Disponível em: http://unesdoc.unesco.org/images/0024/002440/244040por.pdf. Acesso em 04 ago. 2017.

25 WHO (World Health Organization). Don't pollute my future! The Impact of the Environment on Children's Health. 2017. Disponivel em: http://apps.who.int/iris/bitstream/10665/254678/1/WHO-FWCIHE-17.01-eng.pdf. Acesso em 11 jan. 2017.

${ }^{26}$ SOBRINHO, Liton Lanes Pilau; SANTOS, Juliana Fagundes dos. "A sustentabilidade dos recursos hídricos". In: CUSTÓDIO, André Vianna; BALDO, lumar Junior (Org.). Meio ambiente, constituição \& políticas públicas. Curitiba: Multideia, 2011. p. 122. 
ISSN 1981-3694

(DOI): $10.5902 / 1981369432544$

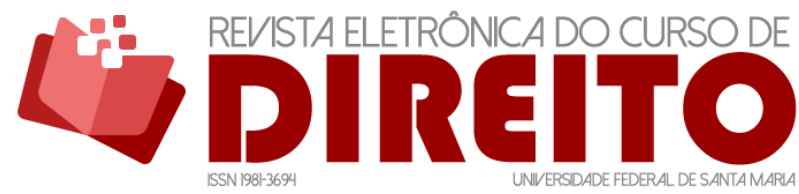

PERSPECTIVAS PARA REDUÇÃO DAS DESIGUALDADES SOCIOAMBIENTAIS GERADAS PELA NÃO CONCRETIZACÃO DO DIREITO HUMANO DE ACESSO Å ÁGUA

peso de água, todas as substâncias que absorve e seu metabolismo dependem de água e é a água a responsável pela sua estabilidade térmica, física e química.”.

Observadas essas noções traçadas acima, como a ideia de justiça ambiental, a ênfase à importância de uma distribuição adequada por meio da gestão solidária, cuja política seria ideal se priorizar o abastecimento de água e de saneamento enquanto houver pessoas sem acesso, analisa-se no próximo tópico as desigualdades geradas a partir da não concretização do direito em tela.

\section{FALTA DE ACESSO À ÁGUA E SANEAMENTO BÁSICO COMO FATOR GERADOR DE DESIGUALDADES SOCIOAMBIENTAIS}

A concretização do direito de acesso à água e ao saneamento promove vários outros direitos humanos. Essa interdependência e indivisibilidade remonta à luta contra a pobreza, que é também consequência da falta expressiva do acesso à água e ao saneamento básico. A Agenda 21, elaborada na Conferência das Nações Unidas sobre Meio Ambiente e Desenvolvimento, realizada pela Organização das Nações Unidas, no Rio de Janeiro, em 1992, assinada e acordada por 179 Países, ao tratar do tema, afirma a necessidade e os desafios de se enfrentar o problema e de aplicar instrumentos e programas específicos às realidades de cada País. Trata-se a pobreza como um problema complexo e crescente simultaneamente a nível nacional e internacional, sem uma solução uniforme. Não obstante, a Agenda 21 utiliza o termo desafio, ao abordar o tema responsabilidade social, em buscar a “(...) erradicação da pobreza e da fome, [a] maior equidade na distribuição da renda e [o] desenvolvimento de recursos humanos". ${ }^{27}$ Frisa-se que o acréscimo do abastecimento da água em seus múltiplos usos é um possível meio de efetivação do combate à pobreza e de todos os direitos humanos declarados.

Dentro dessa compreensão, cabe mensurar a relação entre a pobreza e a falta de acesso aos recursos naturais básicos para a manutenção da qualidade de vida. Essa conexão pode ser demonstrada por meio de alguns índices. Bernardo Kliksberg escreve que a América Latina tem se apresentado frustrada na mensuração do seu desenvolvimento por indicadores usuais de taxas de crescimento anual, como por exemplo o Produto Interno Bruto per capita que cresceu

\footnotetext{
${ }^{27}$ AMBIENTE, Ministério do Meio. Responsabilidade Socioambiental: Agenda 21 Global. 1992. Disponível em: http://www.mma.gov.br/responsabilidade-socioambiental/agenda-21/agenda-21-global. Acesso em: 06 ago. 2017.
} 
conjuntamente com as desigualdades sociais. Em sincronia com o desenvolvimento econômico e o progresso dos índices comuns de mensuração, os aspectos relacionados ao desenvolvimento social, ambiental, acesso à cultura e liberdade, por exemplo, precisam ser considerados. ${ }^{28}$

0 autor referido acima entende que o fator humano deveria ser acrescido na lógica desenvolvimentista atual. Isso se traduziria em o desenvolvimento não se concentrando somente no PIB e no aumento da economia per si, mas considerasse o investimento em educação, infraestrutura, saúde, meio ambiente e áreas afins, para que se busque, efetivamente, a justiça equitativa, superando iniquidades como as existentes pela falta de acesso à água. 0 desenvolvimento somente é válido à medida que potencializa o ser humano em qualidade de vida social, ambiental, política, econômica, etc. ${ }^{29}$

Questiona-se sobre como há altos níveis de desenvolvimento tecnológico, informacional, dentre outros, quando existem altos níveis de miserabilidade no mundo. Não significa apenas olhar e criticar a economia de mercado, mas como as relações sociais nela se formam. Segundo Amartya Sem, existe uma preocupação maior do capitalismo global em “(...) expandir relações de mercado do que, por exemplo, em estabelecer a democracia, expandir a educação elementar ou incrementar as oportunidades sociais para os pobres do mundo". ${ }^{30}$

Além dos índices comumente utilizados, existe e destaca-se o índice de Gini, desenvolvido pelo matemático italiano Conrado Gini, em 1912, cujo propósito é mensurar a concentração de renda e a desigualdade social em determinado país, território, Estado ou comunidade, apontando informações que podem ser limitadas por índices como o PIB e a renda per capita. Gini é demonstrado por meio de uma escala de 0 a 1 ou 0 a 100, em que quanto mais próximo de 0 maior é o nível de igualdade e quanto mais próximo de 1 ou 100 maior é o nível de desigualdade. ${ }^{31}$

Sonia Alvarez Leguizamón ${ }^{32}$ reflete acerca das desigualdades sociais produzidas e acentuadas pela globalização, pela transformação neoliberal e pelo capitalismo mundial. A

${ }^{28}$ SEN, Amartya; KLIKSBERG, Bernardo. As pessoas em primeiro lugar: a ética do desenvolvimento e os problemas do mundo globalizado. São Paulo: Companhia das Letras, 2010. Tradução de: Bernardo Ajzemberg e Carlos Eduardo Lins da Silva. p. 139.

29 Ibid., p. 189.

${ }^{30}$ Ibid., p. 28.

31 WOLFFENBÜTTEL, Andréa. 0 que é? - Índice de Gini. 2004. Disponível em: http: // www.ipea.gov.br/desafios/index.php?option=com_content\&id=2048:catid=28\&ltemid=23. Acesso em: 15 jan. 2017.

32 LEGUIZAMÓN, Sonia Alvarez. Concentración de la riqueza, millionarios y reproducción de la pobreza en América Latina. Sociologias, Porto Alegre, v. 18, n. 9, p.38-73, dez. 2007. Disponível em: http://seer.ufrgs.br/index.php/sociologias/article/view/5648. Acesso em: 15 jan. 2017. 
ISSN 1981-3694

(DOI): $10.5902 / 1981369432544$

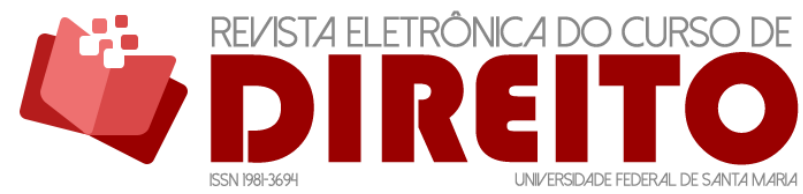

PERSPECTIVAS PARA REDUÇÃO DAS DESIGUALDADES SOCIOAMBIENTAIS GERADAS PELA NÃO CONCRETIZACÃO DO DIREITO HUMANO DE ACESSO Å ÁGUA

autora percebe que mesmo os países latino-americanos se inserindo no mercado mundial e no capitalismo, a desigualdade persiste. Esse fato é atribuído à concentração de renda nas mãos de poucos. Dentro deste contexto, ela destaca que a falta de acesso à água e ao saneamento básico é um dos principais elementos geradores da pobreza. Conforme os índices apresentados em 2004 pela Comissão Econômica para a América Latina e o Caribe (CEPAL), os dados relacionados à pobreza demonstram que $44 \%$ das pessoas são carentes, sendo que aproximadamente $20 \%$ vivem em pobreza extrema e indigência. São comunidades afetadas diretamente pela falta de acesso aos recursos básicos necessários para subsistência. Nesse mesmo período, a Argentina, o Brasil e Honduras passaram para o grupo de maior desigualdade social da América Latina, segundo o coeficiente de Gini.

Em relação à América Latina e ao Caribe, o resumo executivo criado pelo CEPAL, em 2018, para o Fórum Mundial da Água realizado em Brasília indica que esses números melhoraram; contudo, ainda foi observado que 61 milhões de habitantes tem um acesso precário ao saneamento básico adequado e 13 milhões de habitantes não tem acesso a uma fonte de água segura. Desse modo, o problema não está resolvido e requer, dos governantes, aprimorar e colocar nas suas principais pautas o problema. Nessas considerações, não somente o acesso é considerado, mas também a sua qualidade e a sua continuidade. No Peru, por exemplo, das 16 cidades avaliadas, apenas 19\% recebem uma média de 22 horas de abastecimento contínuo, enquanto em 56\% a média ofertada é de 12 horas. No México, apenas 14\% dos domicílios recebem água todos os dias. As áreas rurais têm a situação agravada, tanto na continuidade do serviço ofertado quanto na qualidade do acesso. ${ }^{33}$

A concentração de renda em poucas mãos contribui com a má distribuição dos recursos básicos à sobrevivência humana. Sonia Alvarez Leguizamón enfatiza a causa do empobrecimento da América Latina nos seguintes pontos: flexibilização das leis trabalhistas e falta de cobertura de direitos vinculados ao trabalho, bem como a falta de acesso aos meios de subsistência básicos “(...) para gerar meios para a reprodução da vida, como o acesso à terra, à água ou ao crédito”. ${ }^{34}$

33 (CEPAL), Comissão Econômica Para A América Latina e 0 Caribe. Proceso Regional de las Américas Foro Mundial del Agua 2018: Informe Regional América Latina y el Caribe Resumen ejecutivo 2018. Santiago, Chile: Banco Interamericano de Desenvolvimento, 2018. Disponível em: https://www.cepal.org/sites/default/files/news/files/informe_regional_america_latina_y_caribe.pdf.

Acesso em: 05 dez. 2019.

34 "para generar medios para la reproducción de la vida, como lo son el acceso a la tierra, el agua o el crédito". LEGUIZAMÓN, Sonia Alvarez. Concentración de la riqueza, millionarios y reproducción de la pobreza en América Latina. Sociologias, Porto Alegre, v. 18, n. 9, p.38-73, dez. 2007. Disponível em: http://seer.ufrgs.br/index.php/sociologias/article/view/5648. Acesso em: 15 jan. 2017. p. 40. 
O resultado da restrição do acesso aos direitos aqui postos somente tem por resultado a pobreza. Soma-se o acesso à informação ao quadro exposto, pois reduz a autonomia e a liberdade de escolha do indivíduo.

Nesse sentido, Amartya Sen aponta os graus de liberdade de um indivíduo, onde o progresso acontece à medida que essas liberdades individuais se desenvolvem, sejam políticas, sociais e/ou econômicas. Cada país, de acordo com suas políticas, potencializa uma ou outra liberdade. A saúde é considerada uma das chaves principais para a liberdade de fato, ou seja, permitirá ao ser humano fortalecer e exercer suas capacidades, aproximando-o da justiça social. Ao julgar a saúde como uma das mais importantes condições de vida humana, não é possível ignorá-la em qualquer concepção de justiça desenhada. “Equidade na realização e na distribuição de saúde, portanto, está incorporada e embutida em uma ampla noção de justiça". ${ }^{35}$ A água e o saneamento básico guardam relação direta com a condição física humana. Arranjos sociais inadequados promovem a injustiça social e ambiental por restringir as oportunidades de se promover condições salutares de vida.

\section{REFLEXÕES SOBRE PERSPECTIVAS PARA A REDUÇÃO DAS}

\section{DESIGUALDADES SOCIOAMBIENTAIS GERADAS PELA FALTA DE ACESSO À ÁGUA E AO SANEAMENTO}

Este tópico se direciona para a reflexão sobre as perspectivas acerca do acesso aos recursos hídricos. O propósito é identificar as alternativas que possam consubstanciar uma mudança cultural ou paradigmática devido aos problemas gerados pela falta de acesso à água e ao saneamento básico. Utiliza-se, para tanto, dos ensinamentos de Amartya Sen, Bernardo Kilksberg, John Rawls, Riccardo Petrella, Maude Barlow, Tony Clarke e Fritjof Capra, autores que possuem obras consistentes em relação à temática. Desenvolve-se este título a partir de uma análise da visão mercantilizada da água conjuntamente a princípios que objetivam promover o acesso equitativo deste recurso de acordo com a noção de justiça social e ambiental.

\footnotetext{
${ }^{35}$ SEN, Amartya; KLIKSBERG, Bernardo. As pessoas em primeiro lugar: a ética do desenvolvimento e os problemas do mundo globalizado. São Paulo: Companhia das Letras, 2010. Tradução de: Bernardo Ajzemberg e Carlos Eduardo Lins da Silva. p. 76.
} 
0 século XXI iniciou com indícios da dificuldade de acesso à água por parte da população. Ricardo Petrella assinala que a tendência é a disputa pela água, assim como o petróleo foi no século XX. As “convulsões" que envolvem esses recursos naturais acontecem pela busca de controle e poder. Da mesma forma que se intitulam os "senhores da terra" ou "barões do petróleo", já são conhecidos os "senhores da água". ${ }^{36}$

As regulamentações das relações sobre a água têm se consolidado cada vez mais em um nível internacional, o que é natural em um contexto globalizado e informatizado. As instituições que tem se responsabilizado em tratar do tema e debater normas e padrões referentes aos usos da água são organizações globais, multilaterais e desestatizadas, como, por exemplo, o Banco Mundial e a Organização Mundial do Comércio, e até mesmo organizações estatais supranacionais, como a União Europeia. A demanda é pelo atendimento de uma nova classe social e uma questão que envolve esse sistema: a água como um novo recurso a ser disputado. As organizações, grupos ou empresas que utilizam grandes quantidades de água no seu processo produtivo poderão cooperarem ou disputarem de acordo com os seus interesses e do cenário político e econômico. ${ }^{37}$ Os recursos hídricos representam uma fonte significante de capital, e como tal é utilizado para gerar poder. Quem detém esse recurso tem condições de dominar economicamente e submeter comunidades carentes ao seu julgo. ${ }^{38}$

Os autores Barlow e Clarke ${ }^{39}$ mencionam os senhores da água e exemplificam a sua atuação em um caso de privatização da água, como o ocorrido em Buenos Aires. 0 serviço foi implementado pela empresa privada e os preços estabelecidos de acordo com o mercado. Em dado momento de crise no País, em razão da inflação, os preços aumentaram consideravelmente em determinados períodos, prejudicando o acesso por parte da população mais pobre. Nesse caso em específico, houve um contrato entre governo e a empresa Águas Argentinas, com flexibilidade interna, para auxiliar na proteção das margens de lucro da empresa, e esse acordo permitia que a empresa aumentasse a tarifa caso o índice de custo composto “(...) (um índice baseado no custo de combustível, mão-de-obra e outras despesas) subisse acima de 7\%"40.

\footnotetext{
36 PETRELLA, Riccardo. 0 manifesto da água: argumentos para um contrato mundial. Petrópolis, RJ: Vozes, 2002.

37 PETRELLA, Riccardo. 0 manifesto da água: argumentos para um contrato mundial. Petrópolis, RJ: Vozes, 2002.

${ }^{38}$ PEREIRA, Agostinho Oli Koppe; CALGARO, Cleide. A Água: os reflexos da modernidade. Revista Trabalho \& Ambiente, v. 05, p. 101-111, 2007.

39 BARLOW, Maude; CLARKE, Tony. Ouro azul: como as grandes corporações estão se apoderando da água doce do nosso planeta. São Paulo: M. Books, 2003. p. 124.

40 Ibidem.
} 
Considerando esse cenário, a Universidade Argentina de Administração de Empresas emitiu um relatório cujo teor demonstrava que a Águas Argentinas acumulou, até 1995, “(...) lucros de 28,9\% e em 1996 e 1997 estes valores foram de 25,4\% e 21,4\%, respectivamente”, enquanto “(...) as margens de lucro de empresas de água da Inglaterra e País de Gales consideradas por alguns como modelos de privatização - que tiveram média de 9,6\% em 1998-99 e 9,3\% em 1999-2000."41. Ora, lucros significativos foram auferidos com esse empreendimento. A crítica feita pelos autores se assenta no “(...) fato de que uma corporação privada, cujo principal objetivo era aumentar o lucro, estava fornecendo um serviço que deveria ter sido fornecido pelo governo em uma base não-lucrativa" ${ }^{42} \mathrm{e}$, independente da responsabilidade da corporação transnacional, não servem ao interesse público.

O exemplo exposto denota descaso por parte do Poder Público em cumprir com o seu propósito de "guardiões do suprimento comum". Empresas públicas têm sido geridas sob o viés mercadológico, cujo objetivo principal é o lucro. O “ouro azul”, assim intitulado por Barlow e Clarke, tornou-se objeto de investimento empresarial, consolidando mercados globais de água. ${ }^{43}$

Os argumentos partidários da privatização aludem à possibilidade das corporações, que visam ao lucro, serem mais transparentes que os governos, mas resta a dúvida acerca da realidade: uma empresa cujo objetivo é o lucro não condiz com práticas públicas e a consecução de serviços públicos que concernem, principalmente, a respeito de bens de uso comum essenciais à vida; cumpre ao Estado regulamentar essas práticas sob o enfoque do bem comum, uma vez que, conforme coloca a autora Brzezinski, “(...) a água é parte essencial do direito à vida, e o serviço de captação, de tratamento e de distribuição de água potável compõe o direito à saúde, ambos direitos fundamentais previstos na Constituição Federal". ${ }^{44}$

A primeira perspectiva observada implica justamente no não tratamento da água como um recurso passível de apropriação privada para obtenção de lucro. Converter a água em bem econômico não tem por objetivo “(...) torná-la acessível a toda a população mundial, mas sim levá-la àquilo que afirmam ser um gerenciamento 'economicamente racional' de um recurso limitado cuja acessibilidade deve ser regulada pela solvência dos usuários competindo entre

\footnotetext{
41 Ibidem.

42 BARLOW, Maude; CLARKE, Tony. Ouro azul: como as grandes corporações estão se apoderando da água doce do nosso planeta. São Paulo: M. Books, 2003. p. 124.

43 Ibid., p. 125

${ }^{44}$ BRZEZINSKI, Maria Lúcia N. L. Água doce no século XXI: serviço público ou mercadoria internacional? São Paulo: Lawbook Editora, 2009. p. 71-72.
} 
si”. ${ }^{45}$ Priorizar o valor econômico da água é uma escolha. É possível escolher um viés que contemple outros modos de gerenciamento (política, solidária ou pautada na cooperação).

Outra conjuntura a se pensar é o acesso à informação e como a sociedade vê a hidrogeologia, pois os recursos hídricos estão sendo utilizados massivamente em atividades minerárias, como, por exemplo, o fraturamento hidráulico ${ }^{46}$ para exploração e extração de gás natural de rochas sedimentares, que demandam um grande volume de água para o processo de extração do gás, além de gerar um risco significante de contaminação das águas subterrâneas, pois a rocha que produz o gás por vezes se localiza próximo ou abaixo dos aquíferos. Neste caso, imperiosamente precisaria haver o debate com a sociedade, especialmente com as pessoas impactadas diretamente pela exploração, pelos riscos aos quais são expostas.

A tecnologia é um dos instrumentos atuais para construir um processo contínuo de proteção aos recursos hídricos. Após uma breve análise da evolução do processo de gestão das águas, Tundisi ${ }^{47}$ entende que a tecnologia informacional, dentre outras, deve se fazer presente para uma maior eficiência da governança; isso deve acontecer por meio da participação da sociedade civil, usuários, etc., conforme já dispõe a Política Nacional dos Recursos Hídricos brasileira. O autor desvela de forma sintetizada a gestão dos recursos hídricos no Brasil, sob a crítica de que é preciso unificar e gerenciar em unidade as bacias hidrográficas brasileiras. Isso para distribuir a água e seus usos conforme as necessidades de cada região e setor, com fins de uma distribuição mais equitativa. Cinco princípios podem ser considerados em uma nova perspectiva de gestão: instituições através da pesquisa, desenvolvimento tecnológico e gerenciamento; participação envolvendo a sociedade e de forma regionalizada; tecnologia; informação; e financiamento.

45 PETRELLA, Riccardo. 0 manifesto da água: argumentos para um contrato mundial. Petrópolis, RJ: Vozes, 2002. p. 85-86.

${ }^{46}$ A quantidade de água necessária para a solução de fraturamento é estimada entre nove a quinze milhões de litros de água, dependendo das condições geológicas do local, podendo chegar a 29 milhões de litros d'água em todo o processo de perfuração de um poço. Essa solução é uma fórmula composta por sintéticos "como, por exemplo, benzeno, tolueno, xilenos, etilbenzeno, surfactantes variados, hidrocarbonetos organoclorados, entre outros compostos (poli)alifáticos e (poli)aromáticos". E são esses gases que podem migrar para além da tubulação aos aquíferos adjacentes e, também, para as águas superficiais. AUGUSTIN, Sérgio; SANBERG, Eduardo; GÖCKS, Nara Raquel Alves. Interações entre o direito ambiental brasileiro e as ciências da terra: faturamento hidráulico no Brasil. In: RECH, Adir Ubaldo; MARIN, Jefferson; AUGUSTIN, Sérgio (orgs.). Direito Ambiental e Sociedade. Caxias do Sul: Educs, 2015. p. 278. Disponível em https://www.ucs.br/site/midia/arquivos/E-book-Direito-ambiental-sociedade.pdf. Acesso em: $20 \mathrm{dez} .2017$.

47 TUNDISI, José Galizia. Governança da água. rev. UFMG, belo horizonte, v. 20, n.2, p. 222-235, jul./dez. 2013. 
ISSN 1981-3694

(DOI): $10.5902 / 1981369432544$

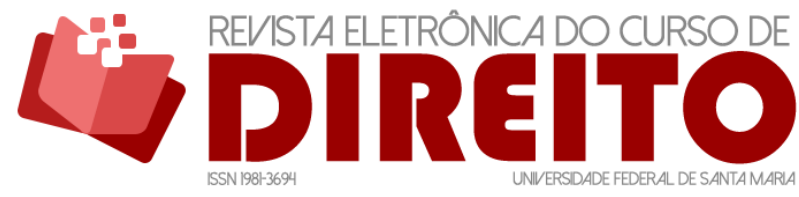

PERSPECTIVAS PARA REDUÇÃO DAS DESIGUALDADES SOCIOAMBIENTAIS GERADAS PELA NÃO CONCRETIZACÃO DO DIREITO HUMANO DE ACESSO Å ÁGUA

Barlow e Clarke apontam que é possível preservar os recursos de água e afastar conflitos a partir da atuação conjunta dos governos e comunidades ao redor do mundo. Chegará um momento em que terá que se pensar a transição de um modelo de abastecimento; atualmente é pauta a transposição de rios, fato polêmico e controverso em razão dos pontos positivos e negativos quanto aos impactos ambientais e sociais dessas ações. Da mesma forma, logo se falará em mudança das comunidades, localizadas em regiões secas, para locais que facilitem o acesso à água.

Considerando esse contexto, seis princípios são indicados para o diálogo e a renovação do olhar sobre os recursos naturais; São eles: “a água pertence à Terra e a todas espécies”, "a água poluída deve ser recuperada”, "a água é um bem público a ser cuidado por todos os níveis de governo", "o acesso a um suprimento adequado de água limpa é um direito básico do ser humano", "os melhores defensores para a água são as comunidades locais e seus cidadãos", e “o público tem de participar como um parceiro igual ao governo para proteger a água". ${ }^{48}$

Todos os princípios reforçam e apresentam o dever de preservação da água através da participação dos cidadãos e governos. Em linhas gerais, chama-se atenção à relação do homem com a natureza e a consciência das suas escolhas sobre ela. Desse modo, assinala-se com veemência a necessidade de utilizar o recurso com cautela e de recuperar a água poluída como um instinto de autopreservação. A água como bem de domínio público faz com que o Estado promova a proteção e a gestão de acordo com as necessidades da população, sem a possibilidade do homem se apropriar ou mercantilizá-la. A segunda perspectiva observada, analisando os princípios expostos, é envolver a sociedade a partir da conscientização do problema. A participação popular, então, reforçaria a possibilidade de concretizar o direito de acesso à água e ao saneamento. Uma opção seria a criação de uma política de precificação com a participação ativa de cidadãos aptos para representar as comunidades mais carentes.

John Rawls trabalha com três princípios hierárquicos, o primeiro é da igual liberdade, o segundo fragmenta-se no princípio da igualdade equitativa de oportunidades e o terceiro é o princípio da diferença. Pode-se atribuir o segundo à desigualdade social gerada pela má distribuição da água, uma vez que, segundo a teoria de Rawls, a justiça se perfaz no momento em que há uma distribuição equitativa dos recursos naturais, com destaque àqueles que não possuem o mínimo necessário para subsistência e, com isso, possa reduzir as desigualdades sociais. A distribuição das riquezas, direitos de liberdade e oportunidades é compreendida como

${ }^{48}$ BARLOW, Maude; CLARKE, Tony. Ouro azul: como as grandes corporações estão se apoderando da água doce do nosso planeta. São Paulo: M. Books, 2003. p. 263-264. 
a distribuição de bens primários sociais. As políticas sociais devem prevalecer com o objetivo de melhorar a posição ou a condição social dos indivíduos. ${ }^{49}$

A cooperação como característica de uma coletividade é pauta principal para buscar a equidade dentro da noção de justiça social de John Rawls. Repisa-se que a injustiça está estabelecida enquanto pessoas morrem por causas evitáveis. Segundo o autor “(...) talvez não seja a desigualdade de renda e de riqueza enquanto tal que nos incomode; podemos pensar que, a não ser que haja uma escassez real, todos deveriam ter pelo menos o suficiente para satisfazer suas necessidades básicas". ${ }^{50} \mathrm{O}$ controle das desigualdades sociais e econômicas seria necessário para impedir que uma parte da sociedade domine outra, impondo um sistema onde muitos têm pouco e poucos têm muito. As bases da cooperação para evitar a desigualdade residem, para John Rawls, na inteligência (educada), na propriedade e na capacidade de associação, a fim de se buscar a realização de interesses políticos voltados para a coletividade e priorizando a redução das mazelas sociais, dirigindo-se para o lado oposto daquele em que há apenas uma classe dominante. ${ }^{51} \mathrm{O}$ envolvimento da sociedade no que se relaciona aos recursos ambientais precisa ser ativo. Assim, há um limiar para a terceira perspectiva relacionada à cultura.

A cultura é um fator interessante a ser trabalhado na busca por uma perspectiva relacionada ao tratamento/gerenciamento dos recursos hídricos. Promover o desenvolvimento humano significa alcançar especialmente as pessoas que estão em situação de pobreza em decorrência da falta de acesso à água e ao saneamento básico. Bernardo Kliksberg, entende que o desenvolvimento envolve também o aspecto cultural. É um dos critérios fundamentais para a avaliação do progresso. A cultura é definida pela UNESCO como as formas de convivência humana que moldam “(...)o nosso pensamento, nossa imagem, formas de expressão e de comunicação e muitos outros aspectos que definem a identidade das pessoas e das nações". ${ }^{52}$ É possível ter uma visão mais ampla do desenvolvimento quando se analisa o capital social. Essa perspectiva permite observar os diversos fatores extra econômicos presentes no desempenho dos países em termos de progresso. E todos estão relacionados com a cultura:

49 CALGARO, Cleide. O programa bolsa família e a teoria da justiça em John Rawls: os direitos fundamentais individuais de liberdade e igualdade na sociedade democrática brasileira. 01. ed. Porto Alegre: Editora Fi, 2015. v. 1. p. 30-31.

${ }^{50}$ RAWLS, John; KELLY, Erin. Justiça como equiidade: uma reformulação. São Paulo: M. Fontes, 2003. p. 184.

${ }^{51}$ RAWLS, John; KELLY, Erin. Justiça como equiidade: uma reformulação. São Paulo: M. Fontes, 2003. p. 184.

52 SEN, Amartya; KLIKSBERG, Bernardo. As pessoas em primeiro lugar: a ética do desenvolvimento e os problemas do mundo globalizado. São Paulo: Companhia das Letras, 2010. Tradução de: Bernardo Ajzemberg e Carlos Eduardo Lins da Silva. p. 302. 
ISSN 1981-3694

(DOI): $10.5902 / 1981369432544$

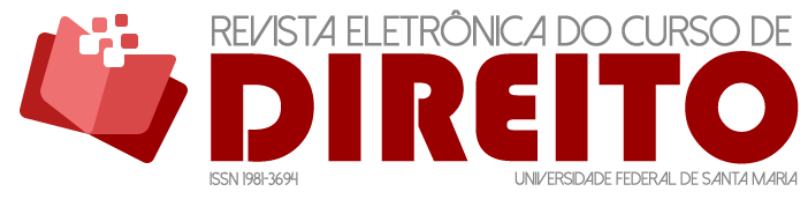

PERSPECTIVAS PARA REDUÇÃO DAS DESIGUALDADES SOCIOAMBIENTAIS GERADAS PELA NÃO CONCRETIZACÃO DO DIREITO HUMANO DE ACESSO Å ÁGUA

a) Capital natural: é constituído pela dotação de recursos naturais;

b) Capital construído pela sociedade: são as infraestruturas, a tecnologia, o capital financeiro, o comercial e outros;

c) Capital humano: é integrado pelos níveis de saúde e educação da população;

d) Capital social: implica em quatro dimensões, são elas o clima de confiança entre as pessoas nas relações interpessoais, isto é, quanto maior a confiança maior será a fluidez nas relações econômicas, quanto menor a confiança maior será o "custo litígio", ou seja, o pagamento a terceiros (advogado, justiça, etc.) para que se cumpram contratos; a segunda dimensão é a capacidade de associatividade, ou seja, a capacidade de motivar a cooperação solidária entre as pessoas, desde a vizinhança até pactos internacionais entre Estados; a terceira dimensão tem relação com a consciência cívica - como as pessoas agem coletivamente, qual o envolvimento nos debates públicos, assim como o cuidado com transporte público, por exemplo, até pagamento de impostos; e por fim, "os valores éticos predominantes numa determinada sociedade". ${ }^{53}$

Para Bernardo Kliksberg, o discurso econômico ortodoxo influenciou a macroeconomia regressivamente deslocando a discussão sobre os valores éticos e apresentando-os como mera questão tecnocrática. Por isso, entende necessário que se retorne à ética em todos os níveis sociais, para que se faça presente culturalmente, exemplificando países que possuem traços culturais éticos, que já tomaram decisões e construíram políticas públicas em diversos setores, desde a economia até a educação e que apresentaram índices satisfatórios sobre a desigualdade social, conforme o índice de Gini. Dentre os exemplos está a Noruega, a Suécia, a Finlândia e a Dinamarca. Em que pese se entenda que o modelo político, econômico e social em que o Brasil está inserido seja único, existem outros que poderiam construir de acordo com a história e cultura de cada localidade uma nova cultura social mais justa ou equitativa. ${ }^{54}$

A quarta perspectiva e colocada como sugestão seria a conversão da visão antropocêntrica para a ecocêntrica. Essas vertentes compreendem de maneira diferente a subjetividade e a objetividade da natureza e do homem. A água não sustenta somente a vida humana, sustenta outras vidas que compõem outros recursos necessários ao equilíbrio do planeta

\footnotetext{
${ }^{53}$ SEN, Amartya; KLIKSBERG, Bernardo. As pessoas em primeiro lugar: a ética do desenvolvimento e os problemas do mundo globalizado. São Paulo: Companhia das Letras, 2010. Tradução de: Bernardo Ajzemberg e Carlos Eduardo Lins da Silva. p. 306.

${ }^{54}$ Ibid., p. 306, 310.
} 
Terra. Capra ${ }^{55}$ contempla a natureza e o homem sob a perspectiva da integração, onde emerge um sistema vivo e complexo em si. Sob essa perspectiva, os autores Waddock e Mclntosh apud Venzke e Nascimento ${ }^{56}$ entendem que, para a construção de uma melhor convivência, seria importante construir uma relação salutar entre a sociedade e as empresas. Adiciona-se a esse fator o Estado por meio da regulamentação dos usos dos corpos hídricos e de políticas públicas voltadas para a proteção do recurso.

Essa reflexão em torno da realidade exposta ao longo do texto implica na necessidade de buscar comportamentos éticos diferentes, em que se estruture um pensar humano e ecológico plausíveis com a preservação do ambiente. 0 pensamento complexo compreendido por Edgar Morin é uma proposta relevante para uma sociedade complexa. ${ }^{57} \mathrm{~A}$ intervenção do homem na natureza, que gera deterioração ambiental e perda da disponibilidade dos recursos naturais próprios à manutenção da vida e ao desenvolvimento humano, acontece de várias formas, com diversos impactos ao mesmo tempo: à fauna, à flora, aos corpos hídricos, etc. Tendo isso em vista, urge a necessidade de uma ética por parte dos indivíduos e da coletividade voltada aos objetivos trabalhados no ecocentrismo.

Por fim, entende-se pertinente o pensar reflexivo sobre o uso das águas por diferentes olhares e, principalmente, debatê-los para além da academia. Nesse entendimento, é possível perceber que as questões que envolvem os recursos hídricos precisam se dar a partir de uma ótica solidária entre as gerações e as espécies. No que toca à sociedade, compreende-se que o indivíduo, ao atuar conforme os princípios ambientais, estará prestando serviço público e perfazendo o acesso contextualizado à justiça. Conforme aponta Di Lorenzo, esse agir do indivíduo incide em um princípio denominado de correlação, em que, ao ser responsável com o bem comum ambiental e, especificamente no caso em análise, ao fazer uso consciente da água, estará em um ciclo virtuoso, "a pessoa fomenta seus próprios direitos fundamentais", como também os da coletividade, sob uma postura solidária. ${ }^{58}$

\footnotetext{
${ }^{55}$ CAPRA, Fritjof. "Alfabetização Ecológica: o desafio para a educação do século 21. In: TRIGUEIRO, André (coord). Meio ambiente no século 21: 21 especialistas falam da questão ambiental nas suas áreas de conhecimento. Rio de Janeiro: Sextante, 2003.

${ }^{56}$ VENZKE, Cláudio Senna; NASCIMENTO, Luis Felipe Machado do. Caminhos e Desafios para a Inserção da Sustentabilidade Socioambiental na Formação do Administrador Brasileiro. Rev. Adm. Mackenzie, vol. 13, núm. 6, maio/jun. 2013, p. 27-54.

${ }^{57}$ VENZKE, Cláudio Senna; NASCIMENTO, Luis Felipe Machado do. Caminhos e Desafios para a Inserção da Sustentabilidade Socioambiental na Formação do Administrador Brasileiro. Rev. Adm. Mackenzie, vol. 13, núm. 6, maio/jun. 2013, p. 27-54.

58 DI LORENZO, Wambert Gomes. "Meio ambiente e bem comum: entre um direito e um dever fundamentais". In: RECH, Adir Ubaldo; MARIN, Jeferson Dytz; AUGUSTIN, Sérgio (Org.). Direito ambiental
} 


\section{CONCLUSÃO}

O acesso à água e ao saneamento é um direito humano básico que, ao ser concretizado, promove uma série de outras demandas que, juntas, constituem a dignidade humana, isto é, geram condições para que uma pessoa viva com suas necessidades primárias supridas e com possibilidade de desenvolver suas capacidades e usufruir das suas liberdades. Ainda que seja óbvia essa afirmativa, o cenário identificado ao longo dos primeiros tópicos desse estudo demonstra que uma parcela significante da população se sustenta em condições precárias pela falta de acesso à água e ao saneamento básico. Em que pese tenha se observado uma melhora nos números em dez anos (2010-2017), os indicadores apontam para a necessidade de os governos colocarem nas suas pautas principais e priorizarem o tema.

Algumas perspectivas foram pensadas a partir desse cenário e da noção de justiça ambiental e social. A primeira e a segunda, respectivamente, envolvem o entendimento de que a água não é passível de apropriação privada para obtenção de lucros, e é preciso envolver a sociedade a partir da sua conscientização sobre o problema para reforçar a participação popular na gestão dos recursos hídricos. Logo, o ideal seria escolher modelos de gerenciamento pautados na cooperação ou sob o viés de uma política solidária, investindo em programas de distribuição de água às comunidades mais necessitadas, assim como metas de saneamento básico para todas as cidades. 0 objetivo principal é tornar a água acessivel a todos, e um dos principais meios de concretizar essa realidade é o uso da tecnologia e da informação. São instrumentos que propiciam maior eficiência na governança hídrica, notadamente incluindo e reforçando a participação da sociedade civil e de usuários nas políticas de uso da água. Nesse contexto, cinco princípios podem auxiliar para essa perspectiva de gestão: instituições através da pesquisa, desenvolvimento tecnológico e gerenciamento; participação envolvendo a sociedade e de forma regionalizada; tecnologia; informação; e financiamento.

A terceira perspectiva está embasada, também no envolvimento da coletividade na busca pela defesa dos seus interesses. As injustiças sociais e ambientais se estabelecem quando dentro dos interesses coletivos existem grupos ou comunidades vivenciando situações de conflitos, seja pela degradação ambiental ou pela má distribuição dos recursos naturais. A base

e sociedade. Caxias do Sul, RS: EDUCS, 2015. p. 75-76. Disponível em: https://ucsvirtual.ucs.br/startservico/PEA/. Acesso em: 21 jul. 2017. 
ISSN 1981-3694

(DOI): $10.5902 / 1981369432544$

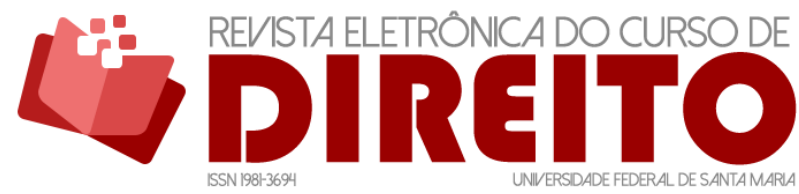

PERSPECTIVAS PARA REDUÇÃO DAS DESIGUALDADES SOCIOAMBIENTAIS GERADAS PELA NÃO CONCRETIZACCÃO DO DIREITO HUMANO DE ACESSO Å ÁGUA

para evitar as causas que geram a desigualdade é a cooperação. Aqui não se trata da desigualdade de renda ou econômica, mas daquela que não fornece as condições mínimas para que se desenvolvam as capacidades que promovem a vida e a liberdade do homem. Assim, uma nação, povo, grupo ou comunidade que tenha entre si pessoas em situação de miserabilidade por falta de água e/ou saneamento básico compartilha dessa necessidade. Por isso, a cultura é um fator interessante a ser trabalhado na busca por uma perspectiva relacionada ao tratamento/gerenciamento dos recursos hídricos. Os traços e a história de um povo são contados a partir do seu olhar sobre a convivência, a imagem, as formas de expressão, dentre outros aspectos que constituem a sua identidade.

A quarta perspectiva tem relação com as formas de olhar e tratar o meio ambiente pelo sistema brasileiro, isto é, a ênfase que as esferas política, judiciária e legislativa constroem para tudo o que envolve o meio ambiente ecologicamente equilibrado. Atualmente, é convencionada a visão antropocêntrica, onde a preservação da natureza encontra o seu propósito na manutenção da qualidade de vida humana. A conversão ou a harmonização desta com a visão ecocêntrica poderia encontrar um meio-termo para o entendimento e a concretização das perspectivas anteriores. A percepção da integração do homem com a natureza avalia a preservação de ambos, considerando o sistema cíclico e complexo em si. Para incorporar essa perspectiva seria necessário reconstruir comportamentos éticos desde os poderes legislativo, judiciário e executivo até a última camada social. Significa reestruturar um pensar humano ecológico e ético, entendendo como a intervenção na natureza pode gerar a degradação, perda da disponibilidade dos recursos naturais e da própria manutenção da vida e do desenvolvimento humano.

Não se sugere a não intervenção humana, mas sim suscitar na sociedade o debate sobre a necessidade da exploração contínua de recursos naturais, isto é, até que ponto está se intervindo no ambiente para manter a qualidade de vida humana e suprir as necessidades básicas e até mesmo supérfluas, e até que ponto se está apenas acumulando riquezas. A sociedade está inserida no ambiente como parte integrante do ecossistema terrestre. 0 paradigma atual, individualista, reflete diretamente no modo e na qualidade de vida premente das pessoas e no processo de degradação ambiental. Traz consigo a cultura do consumo, cuja consequência é a rápida degradação dos meios naturais para abastecimento do mercado. Seria adequado perpassar a construção da lógica sobre o gerenciamento e a utilização dos recursos hídricos pela educação ambiental. Esta pode ser utilizada como um meio de transmutar essa cultura, tornando os indivíduos cada vez mais responsáveis quanto à influência que podem causar no meio em que 
habitam, isto é, efetivar a participação popular em todos os níveis educacionais, convencionais e não convencionais, para ampliar a consciência voltada ao entorno, abrindo oportunidades para uma política realmente fraterna, cuja efetivação impacta no desenvolvimento sustentável e humano.

\section{REFERÊNCIAS}

ACSELRAD, Henri. Justiça ambiental e construção social do risco. In: Desenvolvimento e Meio ambiente, [s.l.], v. 5, p.49-59, 19 jun. 2002. Universidade Federal do Paraná. http://dx.doi.org/10.5380/dma.v5i0.22116. Disponível em: https://revistas.ufpr.br/made/article/view/22116/14480. Acesso em: 02 dez. 2019.

AMBIENTE, Ministério do Meio. Responsabilidade Socioambiental: Agenda 21 Global. 1992. Disponível em: http://www.mma.gov.br/responsabilidade-socioambiental/agenda-21/agenda21-global. Acesso em: 06 ago. 2017.

ASSEMBLEIA GERAL DA ONU (AG). Resolução 64/292. AG Index: A/RES/64/292, 28 de julho de 2010. Disponível em: http://www.un.org/en/ga/search/view_doc.asp?symbol=A/RES/64/292. Acesso em 06 ago. 2017.

AUGUSTIN, Sérgio; SANBERG, Eduardo; GÖCKS, Nara Raquel Alves. Interações entre o direito ambiental brasileiro e as ciências da terra: faturamento hidráulico no Brasil. In: RECH, Adir Ubaldo; MARIN, Jefferson; AUGUSTIN, Sérgio (orgs.). Direito Ambiental e Sociedade. Caxias do Sul: Educs, 2015. p. 278 Disponível em https://www.ucs.br/site/midia/arquivos/E-book-Direitoambiental-sociedade.pdf. Acesso em: $20 \mathrm{dez} .2017$.

BARLOW, Maude; CLARKE, Tony. Ouro azul: como as grandes corporações estão se apoderando da água doce do nosso planeta. São Paulo: M. Books, 2003.

BRASIL. Sistema Nacional de Informações Sobre Saneamento. Ministério do Desenvolvimento Regional. Ministério do Desenvolvimento Regional publica diagnósticos da situação do saneamento no Brasil. 2019. Disponível em: http://www.snis.gov.br/component/content/article?id=175. Acesso em: 02 dez. 2019.

BRZEZINSKI, Maria Lúcia N. L. Água doce no século XXI: serviço público ou mercadoria internacional? São Paulo: Lawbook Editora, 2009, 251 p.

BRZEZINSKI, Maria Lúcia N. L. O Direito à Água no Direito Internacional e no Direito Brasileiro. Niterói: Confluências, v. 14, n. 1, dez. 2012. Disponível em:

http://www.confluencias.uff.br/index.php/confluencias/article/viewFile/296/240. Acesso em: 09 ago. 2017.

CALGARO, Cleide. O programa bolsa família e a teoria da justiça em John Rawls: os direitos fundamentais individuais de liberdade e igualdade na sociedade democrática brasileira. 01. ed. Porto Alegre: Editora Fi, 2015. v. 1. 
CAPRA, Fritjof. Alfabetização Ecológica: o desafio para a educação do século 21. In: TRIGUEIRO, André (coord). Meio ambiente no século 21: 21 especialistas falam da questão ambiental nas suas áreas de conhecimento. Rio de Janeiro: Sextante, 2003.

CEPAL, Comissão Econômica Para A América Latina e O Caribe. Proceso Regional de las Américas Foro Mundial del Agua 2018: Informe Regional América Latina y el Caribe Resumen ejecutivo 2018. Santiago, Chile: Banco Interamericano de Desenvolvimento, 2018. Disponível em:

https://www.cepal.org/sites/default/files/news/files/informe_regional_america_latina_y_carib e.pdf. Acesso em: 05 dez. 2019.

CUADROS, Gregorio Mesa. Una Idea de Justicia Ambiental: Elementos de conceptualización y fundamentación. Bogotá: Universidade Nacional de Colombia, 2018.

DI LORENZO, Wambert Gomes. Meio ambiente e bem comum: entre um direito e um dever fundamentais. In: RECH, Adir Ubaldo; MARIN, Jeferson Dytz; AUGUSTIN, Sérgio (Org.). Direito ambiental e sociedade. Caxias do Sul, RS: EDUCS, 2015. Disponível em:

https://ucsvirtual.ucs.br/startservico/PEA/. Acesso em: 21 jul. 2017.

FENSTERSEIFER, Tiago. Direitos fundamentais e proteção do ambiente: a dimensão ecológica da dignidade humana no marco jurídico constitucional do estado socioambiental de direito. Porto Alegre: Livraria do Advogado, 2008.

LEGUIZAMÓN, Sonia Alvarez. Concentración de la riqueza, millionarios y reproducción de la pobreza en América Latina. In: Sociologias, Porto Alegre, v. 18, n. 9, p. 38-73, dez. 2007. Disponível em: http://seer.ufrgs.br/index.php/sociologias/article/view/5648. Acesso em: 15 jan. 2017.

ORGANIZAÇÃO PAN-AMERICANA DA SAÚDE (Brasil). Quase 16 milhões de pessoas ainda defecam ao ar livre na América Latina e no Caribe. 2019. Disponível em:

https://www.paho.org/bra/index.php?option=com_content\&view=article\&id=6063:quase-16milhoes-de-pessoas-ainda-defecam-ao-ar-livre-na-america-latina-e-no-caribe\&ltemid=839. Acesso em: 02 dez. 2019.

PADILHA, Norma Sueli. Fundamentos Constitucionais do Direito Ambiental Brasileiro. Rio de Janeiro: Elsevier, 2010.

PEREIRA, Agostinho Oli Koppe; CALGARO, Cleide. A Água: os reflexos da modernidade. In: Revista Diritto e Diritti, [S.I], 2008. Disponível em: https://www.diritto.it/a-agua-os-reflexosda-modernidade/. Acesso em: 15 jan. 2017.

PETRELLA, Riccardo. 0 manifesto da água: argumentos para um contrato mundial. Petrópolis, RJ: Vozes, 2002.

PIOVESAN, Flávia. Temas de direitos humanos. 2.ed. rev. ampl. e atual. São Paulo: M. Limonad, 2003. 
RAWLS, John; KELLY, Erin. Justiça como equiuidade: uma reformulação. São Paulo: M. Fontes, 2003.

SANTOS, Ruth; MENEZES, Renata. A necessidade de realização de políticas públicas para a universalização do direito ao saneamento básico. In: Rev. Bras. Polít. Públicas (Online), Brasília, v. $6, \mathrm{n}^{\circ} 2,2016$. p. 264-279.

SEN, Amartya; KLIKSBERG, Bernardo. As pessoas em primeiro lugar: a ética do desenvolvimento e os problemas do mundo globalizado. São Paulo: Companhia das Letras, 2010. Tradução de: Bernardo Ajzemberg e Carlos Eduardo Lins da Silva.

SOBRINHO, Liton Lanes Pilau; SANTOS, Juliana Fagundes dos. "A sustentabilidade dos recursos hídricos". In: CUSTÓDIO, André Vianna; BALDO, lumar Junior (Org.). Meio ambiente, constituição \& políticas públicas. Curitiba: Multideia, 2011.

TUNDISI, José Galizia. Governança da água. rev. UFMG, Belo Horizonte, v. 20, n.2, p. 222-235, jul./dez. 2013.

VENZKE, Cláudio Senna; NASCIMENTO, Luis Felipe Machado do. Caminhos e Desafios para a Inserção da Sustentabilidade Socioambiental na Formação do Administrador Brasileiro. Rev. Adm. Mackenzie, vol. 13, núm. 6, maio/jun. 2013, p. 27-54.

WHO (World Health Organization). Don't pollute my future! The Impact of the Environment on Children's Health. 2017. Disponível em:

http://apps.who.int/iris/bitstream/10665/254678/1/WHO-FWC-IHE-17.01-eng.pdf. Acesso em 11 jan. 2017.

WHO/UNICEF. Progress on Drinking Water, Sanitation and Hygiene: 2017 Update and SDG Baselines. Geneva: World Health Organization (WHO) and the United Nations Children's Fund (UNICEF), 2017. Disponível em:

http: //www.unicef.pt/artigo.php?mid=1810\&m=\&sid=181016\&cid=6345. Acesso em: 04 de ago. 2017.

WOLFFENBÜTTEL, Andréa. 0 que é? - Índice de Gini. 2004. Disponível em:

http: / / www.ipea.gov.br/desafios/index.php?option=com_content\&id=2048: catid=28\&ltemid=23. Acesso em: 15 jan. 2017.

WWAP (United Nations World Water Assessment Programme). Relatório Mundial das Nações Unidas sobre Desenvolvimento dos Recursos Hídricos 2016: Água e emprego. Resumo executivo. Paris, UNESCO. 2016. Disponível em:

http://unesdoc.unesco.org/images/0024/002440/244040por.pdf. Acesso em: 04 ago. 2017.

WWAP (United Nations World Water Assessment Programme). Relatório Mundial das Nações Unidas sobre Desenvolvimento dos Recursos Hídricos 2016: Água e emprego. Resumo executivo. Paris, UNESCO. 2016. Disponível em: http://unesdoc.unesco.org/images/0024/002440/244040por.pdf. Acesso em: 04 ago. 2017. 


\section{COMO FAZER REFERÊNCIA AO ARTIGO (ABNT):}

MARIN, Jeferson Dytz; BURGEL, Caroline Ferri. Perspectivas para redução das desigualdades socioambientais geradas pela não concretização do direito humano de acesso à água. Revista Eletrônica do Curso de Direito da UFSM, Santa Maria, RS, v. 15, n. 2, e32544, maio./ago. 2020. ISSN 1981-3694. DOI: http://dx.doi.org/10.5902/1981369432544. Disponível em:

https://periodicos.ufsm.br/revistadireito/article/view/32544. Acesso em: dia mês. ano.

Direitos autorais 2020 Revista Eletrônica do Curso de Direito da UFSM

Editores responsáveis: Rafael Santos de Oliveira e Angela Araujo da Silveira Espindola

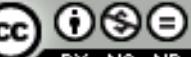

Esta obra está licenciada com uma Licença Creative Commons Atribuição-NãoComercial-SemDerivações 4.0 Internacional.

\section{SOBRE OS/AS AUTORES/AS}

\section{JEFERSON DYTZ MARIN}

Coordenador e Professor do Programa de Pós-Graduação (Mestrado e Doutorado) em Direito da UCS, ministrando as disciplinas Jurisdição Ambiental e Novos Direitos (Doutorado), Processo Ambiental e Jurisdição e Teoria da Decisão e Direito Ambiental (Mestrado). Líder do Grupo de Pesquisa Alfajus, com esforço de cooperação com a Pace Law School - Nova Iorque/EUA e Università di Padova/ITA. Sócio-Fundador da Marin Advogados Associados. Possui Doutorado em Direito UNISINOS (2010) e Mestrado em Direito - UNISC (2005). Autor dos livros Relativização da Coisa Julgada e inefetividade da jurisdição (2015), Crise da Jurisdição e Decisionismo em Alexy: Prisioneiros da Liberdade (2015), As razões da crise do processo na teoria de Ovídio Baptista da Silva (2017), Jurisdição ambiental: A influência da jurisdição italiana e do sistema inglês no processo ambiental brasileiro (2019), Processo Ambiental: características da tutela específica e temas essenciais (2019), Teoria do Processo e Ineficácia da Jurisdicãa (no prelo) (2020) e Decisão Jurídica: Crise da Jurisdição, Driscricionariedade e a Teoria de Ronald Dworkin (no prelo) (2020), dentre outros. Organizador da coleção "Jurisdição e Processo", com quatro volumes. Tem experiência na área de Direito Público, com ênfase em Direito Processual, Constitucional e Ambiental, atuando principalmente nos seguintes temas: jurisdição constitucional e ambiental, teoria da decisão e processo civil.

\section{CAROLINE FERRI BURGEL}

Mestre em Direito pela Universidade de Caxias do Sul com área de concentração em Direito Ambiental. Bacharel no curso de Direito da Universidade de Caxias do Sul. Bacharel no curso de Administração da Universidade de Caxias do Sul (2016). Bolsista de iniciação científica BIC/UCS (2015-2016). Bolsista Capes (2017-2019). 